\title{
Home Spirits in the Udmurt Mythology
}

\author{
Tatiana Vladykina \\ e-mail: tgvladykina@mail.ru \\ Galina Glukhova \\ e-mail: galant@udm.ru
}

\begin{abstract}
Udmurt spirits had a clear hierarchy, with each one of them functioning in their own specific field. The article investigates the spirits of domesticated space, including korkamurt, korkakuz'o, s'us'etka (lit: 'man from/of the house, the master of the house, sus'etka'), bannik ('bathhouse spirit') / munchomurt, munchokuz'o (lit: 'man from/of the bathhouse, master of the bathhouse') and the master of the cowshed / gidmurt, gidkuz'o (lit: 'man from/of the cowshed').
\end{abstract}

Keywords: bathhouse spirit, house spirits, master of the cowshed, Udmurt mythology

Mythological plots still prevail in modern Udmurt folklore, contributing to the genre of bailichkas and narrations ishan-mad', literally: 'a story [about] a ghost') (Kel'makov 1981, 1990; Pletneva 1999; Slesareva 2004, 2005; Glukhova 2004; Vladykina 2009; Vladykina, Glukhova 2011; Vladykina, Panina 2015; Panina 2017, and others). The images of mythological characters in these stories are not as 
diverse as they used to be, but they bear witness to the preservation of ancient beliefs and the evolution of a number of deities and spirits. There is information in $19^{\text {th }}$-century sources about the fact that the number of Udmurt gods, deities and spirits reached 40 (see: Vladykin 1994: 96-97). There was a clear hierarchy with each one of the spirits functioning in their own specific field. Just like other peoples living in the forest belt, the Udmurt had two circles of mythological characters: deities/spirits of wild nature and spirits of domesticated space. Both have evolved to some degree, mainly in their appearance. The spirits of domesticated, or domestic, space include korkamurt, korkakuz'o, s'us'etka (lit: 'man from/of the house, master of the house, sus'etka'), bannik (bathhouse spirit) / munchomurt, munchokuz'o (lit: 'man from/of the bathhouse', 'master of the bathhouse') ${ }^{1}$ and the master of the cowshed/gidmurt, gidkuz'o (lit: 'man from/of the cowshed').

In the Udmurt traditional homestead, an izba (korka) occupied the central position among other buildings in the yard (which were the family sanctuary/kuala, barn, granary/kenos, cowshed/gid and bathhouse/muncho). A high fence with large gates surrounded the buildings, marking the enclosed space, i.e. the yard/azbar, and representing the independent, integral household (Orlov 1999: 38). In the $1930^{\text {s }}$, researchers compared the Udmurt yard to a castle (Belitser and others, 1931: 21) because every large patriarchal family ${ }^{2}$ would produce everything they needed for domestic consumption within their own household (Vladykin 1994: 264). It is for good reason that the Udmurt associated the image of the perfect life in their prayers/kuris'kon, with the peasant homestead, thinking of it as a "perfect world" (Vladykin 1994: 312). Peasant homesteads were opposed to the outside world, which was strange, unfamiliar and unknown; the homestead was perceived as the centre of the world/microcosm.

The house protected its inhabitants not only against bad weather, but also against hostile forces. So that family life would be happy, abundant and peaceful, every home owner was very careful 
when selecting the place for construction. For example, building a house at a crossroads was not allowed, as was building on the site of another house that had burned down, in small ravines, diagonally opposite an old house, etc. It was believed that life in such a house would not be happy or abundant. When building a house, people would also adhere to certain beliefs, and hold rituals in order to ensure certain outcomes (see: Shklyayev 1989; Orlov 1999).

The prosperity of a dwelling was also dependent on each resident themselves. In accordance with religious and mythological perceptions, every family member was supposed to follow a number of set rules and taboos. If these were violated, another member of the household, i.e. korkakuz'o, made his presence felt.

Korkamurt, or man [from] the house, is the most widespread and neutral semantical notion. Its synonyms are the dialectic notions of korkakuz'o, yurtkuz'o master of the house and domut'is'/ korkaut'is' guardian of the house. Negative changes in status are obvious in such terms as korkaperi, i.e. an evil spirit of the house, busturgan and s'us'etka, from the Russian susedka/susedko, i.e. neighbour, and vyzhulkuz'o, i.e. master of the cellar.

Korkakuz'o is very rarely depicted as a human being in folklore, but is mainly referred to as an invisible creature. This is why his appearance can only be reconstructed from details. According to some archaic beliefs, he is a hairy creature "like a monkey", and you must not say his name at night so that he "does not grow extremely large, like a haystack" (Vereshchagin 1996: 91). The hairiness is emphasised in particular in the tradition of the northern Udmurts: "Gondyr is the name that the closest relative of Korkamurt is known by to the Votyaks in Glazov Uyezd, i.e. the house spirit who is in charge of supplies, living in the cellar if the house has one, and in barns. His main place of living is the underlying structure of the house. The appearance of Gondyr correlates with his name; the punishment he inflicts on people who have made him angry consists of a rapid reduction in the volume of supplies" (Pervukhin 1888: 91-92). In the author's opinion, this type of house spirit is 
the most ancient and the least Russified, compared to the names listed above (Perkvuhin 1888: 92).

In the course of its evolution, the house spirit has gradually acquired the features of a human being, and correspondingly the components of $\mathrm{murt} / \mathrm{human}$ being and $k u z$ 'o/master in his name. According to some descriptions, he is "an elderly man who always wears a sheepskin coat with the fur inside out" (Pervukhin 1888: 90), "a manlike creature ... who sometimes takes the form of the master of the house himself" (Emel'yanov 1921: 116). On the whole, according to the beliefs of the Udmurts, korkakuz'o was not distinguished by gender and was in charge of both men's and women's work (Pervukhin 1888: 90). At night he would help family members do some housework, for example, spinning and weaving, or splitting firewood (Pervukhin 1888: 91; Emel'yanov 1921: 116). Sometimes korkakuz'o could even be touched or caught

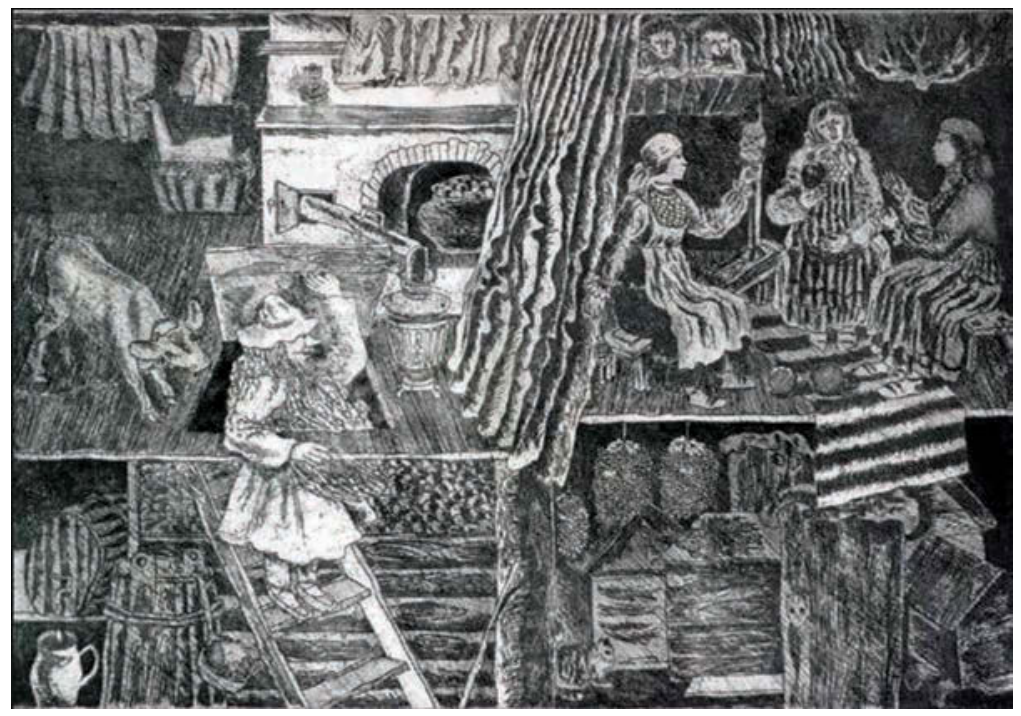

Illustration 1. Picture by Mensadyk Garipov. Korkakuz'o dzhyt pukonyn (The house spirit at an evening gathering). 
in the dark. If someone managed to do so, they would ask it to light a candle. It was believed that "if you saw the house spirit in the light, later on he would have to obey the orders" of the person who caught him (Pervukhin 1888: 90). On the whole, korkamurt was regarded as a kind and useful creature, since he protected the family from other korkakuz'o and guarded the house. The whole house $(i z b a)$ was under his influence.

He could get angry if family members violated standard rules of behaviour: in everyday life one was not allowed to have fun without good reason, or laugh or talk loudly or have rows ${ }^{4}$, otherwise he would remind family members of his existence by torturing them in their sleep, messing up their hair or beard, or doing harm while they worked. Korkakuz'o could replace a child, which is why one was never allowed to leave a new-born baby alone in the house. If a child was not developing normally (was sick all the time, crying or refusing to eat or sleep), people would say "s'us'etka voshtem" ('replaced by s'us'etka'). To guard the child people would put scissors, a knife or a piece of bread at the head of the cradle.

In some individual local traditions, when moving to a new house people would invite the house spirit from the old house to join them. As a rule, they made a small doll, put it in shoes made from bast and took it to the new house, singing wedding songs. In the new house, they would put a bast shoe beneath the stove or in the cellar. After settling in the new house, the house owners would hold a party known variously as korka pyron 'housewarming party', korka s'uan 'wedding/ party in izba' or korka s'ektan 'house treat'. The range of notions for this kind of party also includes korkamurt s'ektan, i.e. 'the feast/treat for korkamurt'. In ethnographic sources from the $19^{\text {th }}$ century there is information that tells us that before the celebration, or directly afterwards, and sometimes even instead of it, a sacrament ritual was held called gulbeche siz'kon. The husband and wife went down into the cellar, taking one pancake, house wine and a young spruce as tall as one $\operatorname{arshin}^{5}$ with them. In the cellar, the owner of the house would stick the spruce in the 
floor in the front corner of the house, break off one small branch and drop to his knees in front of the spruce. The wife would put a tablecloth in front of him and put the pancake on it. Then she would pour house wine into a glass and hand it to her husband. The husband, holding the glass in his right hand and the branch in his left hand, would pray to the supreme god Inmar, asking for a happy life in the new house until old age. Then he made a promise to offer up a black sheep or other four-footed animal as a sacrifice (Vereshchagin 1995: 70; Emel'yanov 1921: 117) so that busturgan "would not haunt the people living in the house" (Vereshchagin 1995: 70). The sacrifice was made some time later in the house or in the cellar. While the sacrificed animal was being cooked, the house owner would pray on his knees, asking for happiness, wealth and all earthly blessings to enter his house; the bones of the sacrificed animals were buried in the ground in the cellar. Such a sacrifice was referred to as gulbeche taka vös'an, 'sacrificing a sheep in the cellar' (ibid.). Contemporary researchers believe that this type of ritual, interpreted as a sacrifice to the house spirit, was not like this, in fact. Most probably it was "a sacrifice to the earth aiming to pass productive/fertile forces on to the people living in the house. As a rule, no such sacrifice was made to the house spirit. Besides, gifts to him were never buried in the ground" (Shklyayev, manuscript).

In modern recordings, there are abundant texts about korkakuz'o and his appearance is more specific. He is also described as a creature with fur or feathers, in the shape of either a hen or a rooster with only one eye. He can also be a small man with a long white beard. However, much more widespread is the anthropomorphic image of a man with beard, wearing white clothes:

Yashkaos doryn kölykum, olokytys' tusho ad'ami potem.

When I was sleeping at Yashka's house, a bearded man appeared from nowhere') (FE 1984'): 
Korkakuz'o - so töd'y dis'en, badzh'ym tusho marke.

The house spirit is someone wearing white clothes, with a long white beard (FE 19947).

Sometimes it is a creature of a dual nature with abnormal features:

Odig kyshnomurt uzhany koshkem no Van'ush n'imo pize ognaz kel'tem. Piyez iz'e vylem. Shödem no, az'az sytshe kuz' yyrs’iyo kyshnomurt, pe, syle. S’in”yosyz no ogkad'es'övöl, pe, ad'amilen, suy-pyd"yosyz ikyr-kukyres', pe.

One woman went to work and left her son Vanyushka alone. He was sleeping. But when he woke up, he saw a woman with long hair standing right in front of him. And she had different eyes, that woman, and her arms and legs were crooked (FE 1982 ${ }^{8}$ );

Mil'am brat shue: “Gulbechys'tuzh badzh'ym, pas'kyt s'inmo ad'ami potiz".

Our brother told us: "A man with very big rolling eyes stepped out of the cellar" (FE 1982).

In Udmurt mythological prose recorded in the late $20^{\text {th }}$ century, korkakuz'o is most often represented as a white man-like creature that is small, of regular height or very tall:

Pichi dyr"ya, tshapak raskulachit' karonles' az'lo, tatshe ishan adzh'i. Soku suzere chachayen vis'e val. Odig uye sendrays'tym vas'kono lui, gulbeche myni (az'lo gulbech gur berez shuo val). Gulbeche lyktysa gine vui no, az'am mon bydzh'a ik töd'y ad'ami potiz. Kurdasa kes'as'kis'ko, beryktis'ki no - so s'öram lykte. 
During my childhood, right before we were dekulakised, I saw a ghost. My sister was sick with smallpox at the time. One night I had to get off my bunk on top of the stove and go to a place behind the stove. And when I went around behind the stove, a white man much taller than me appeared right in front of me. I cried out in fear; and when I turned around, he was following me (FE $\left.2003^{10}\right)$.

Korkakuz'o is most often invisible and intangible in his physicality. However, from time to time he can reveal himself by making a noise or by knocking:

Tan'i, shuo, gur vyle, pe, ishan"yos tubyny ug bygato. Nosh mon gur vylyn kölis'ko. Kin ke tshash-pash kare.

They say ghosts can't climb on the stove. I sleep on the stove. And I can hear someone rustling about right next to me all the time (FE $\left.1991^{11}\right)$ :

Odigaz guzhem dzhyte kerttis'kysa pukis'ko val. Kin ke no korka pyriz-pyd kuaraos kylis'kizy. Lyktiz so guraz'e. Dzhök vylyn marke no shaltyrtem kuara kylis'ke.

One summer evening I was sitting doing some knitting when I heard someone enter the house. I heard footsteps. He went into the kitchen. I heard dishes rattling on the table (FE 1989 ${ }^{12}$ ).

Concepts of the localisation of the house spirit are often related to the stove, i.e. the family hearth, and the surrounding space (you can see him on, behind or under the stove):

Uin kölykumy, anayelen umme us'emez luymte, soin ik so adzh'em, kyz'y gulbech s'örys' kin ke no potiz tuzh kuz'gono, punyly kel'shis'. 
While everyone else was sleeping one night my mother could not get to sleep, and she saw someone walking from behind the stove, with long hair; he looked like a dog (FE 1991 $\left.{ }^{13}\right)$.

But most often korkamurt emerges from the cellar or stands next to it, and 'disappears' into the cellar as well:

Kuchyranys' Maykova Irina adzh'em: murdzholys' potem, kak budto kytshe ke ad'ami.

Irina Maikova from Kuchyran village witnessed the following: it seemed like some kind of man stepped out from the cellar (FE 1984 UIHII of USU - 1984 ${ }^{14}$ ).

His favourite place seems also to be an attic, where his footsteps can often be heard:

Ogpol, 8 chase, pe, korka s’igti olokin kuazh-kuazh vetle, völdetys' lampayez ule-vyle dzhutka no lez'ya.

Once, at about 8 o'clock, we heard footsteps in the attic, and the light bulb right beneath the ceiling was pulled up and down (FE 1975 $\left.{ }^{15}\right)$.

Modern beliefs about the house spirit are mainly related to negative phenomena. It is believed that korkamurt appears before people before something bad happens, informing them about the impending death or illness of relatives. Quite often he appears in the shape of the master of the house:

Kartelen kulon mataz in'i, nosh nonok nontysa kyl'l'is'ko taz'y no, vyzhulys' nosh potiz ad'ami. So kad'ik, karte kad' $i k$, dis'as'kemyn: voyennoy, kyk kruzhka vu yuiz no, doram lyktysa, taz' syle divan pumam. Ug no koshky, ug no mara. 
Mon Vit'i ik shuko, karte ik. Taz'y beram kime lez'i no, so dumbyl'ak beram kyl'l'e, so ves' syle al'i. "Kozma! Ta ved' korkamurt", - shui no, otchy ik bytmiz srazu.

Shortly before my husband's death I was in bed, breastfeeding my child, when a man stepped out of the cellar. He looked just like my husband and was wearing military dress. He drank two cups of water and came closer to me, standing near the sofa. And he clearly wasn't going to leave. I thought it was Vitya, my husband. But then I put my hand behind me, and he (her husband) was lying there as usual, while this man was still standing right in front of me. "Oh my God! It's korkamurt!" I said, and he disappeared (FE 2003 ${ }^{16}$ );

Tatshe deymon ad'amiyez adzh'ysa, piyash kyshkatskem tuzh zol. N'eznay, olokyz'y todiz na so (Van'ush) verany: gulbechys' potem so. Soin todis'kom, so korkakuz'o vylem shuysa. Soye adzh'em beraz, so pi vis'yny kutskiz no tuzh kuradzh'ysa kuliz.

When he saw the man, who was very frightening, the boy became incredibly scared. He (Vanyusha) could hardly speak, but he said: he stepped out of the cellar. This is why we know that it was korkamurt. After what he had seen the boy got sick and died in pain (FE 1982 ${ }^{17}$ );

Potamez ishanly luem. Anayez no atayez tshosh kulil'l'am.

[His] emergence became an omen of death. The mother and father died together (FE UIHII of USU 1984 ${ }^{18}$ ).

One of the surest remedies for healing sick people among peasants was pleasing the house spirit by 'feeding' him. A treat for him was seen as a simplified form of sacrifice, which is why he was also treated with caution: 
Vyl' korkas' gurez nyrys'se estyku, odno ik taban' pyzho.

In a new house, when the stove is stoked for the first time, sour flat pancakes taban' are always made (FE $\left.1983^{19}\right)$.

Thus, in today's perception, the house spirit takes the shape of a human being with certain abnormal features. His zoomorphic features can also be perceived as abnormalities. The image of the house spirit is often exaggerated. In the modern tradition, korkamurt often appears as a prophet or a harbinger praying and showing himself before something bad happens or a person falls seriously ill or dies. He appears on the threshold: at midnight or midday, and sometimes during twilight.

Another demonological character of the Udmurt household is "bathhouse spirit", munchokuz'o "master of the bathhouse", munchomurt "bathhouse man", muncho-Mar"ya "bathhouse Mar"ya", mynchokukn'ik "bathhouse man kukn'ik", mynchopochetka "bathhouse man pochetka", or töd'y-murt "white man". In folklore and ethnographic sources from the $19^{\text {th }}$ century, the bathhouse man is many-faced, and his nudity, hairiness, long hair and huge eye are also often mentioned. One feature common to all descriptions of munchokuz'o is that he does not have an invariable appearance, but can look completely different in different visions. Sometimes his short stature is emphasised. "The bathhouse man was a oneeyed creature with long hair, but sometimes he was perceived as a small, hairy dwarf" (Emel'yanov 1921: 120); "the bathhouse man has the appearance of a small, hairy dwarf" (Pervukhin 1888: 120). Sometimes he is described as a tall, middle-aged man wearing a white shirt and trousers (Pervukhin 1889: 95). His appearance can be exaggerated: "He [the guy] had barely run 10 sazhen $^{20}$ when he looked around and saw Munchomurt (the bathhouse spirit) running after him in the shape of a huge haystack" (Vereshchagin 2001: 41). The bathhouse spirit can also look amorphous: "this creature seems to be... an animal without bones, like jelly, with long 
hair and one huge eye like a moon..." (Vereshchagin 1996: 89). He could appear in the shape of a man or a woman: "the naked, hairy, long-haired, big-eyed Munchomurt is dancing in the bathhouse, and his wife is sitting on the stove and breastfeeding their two children..." (Vereshchagin 2001: 42). A female munchomurt looks unkempt: "a black, ugly, long-haired woman is sitting on the stove whisking her child, holding him on her knees...” (Ibid.: 38).

The bathhouse spirit appeared to young people in the shape of youngsters: "we heard a nice (cheerful) song from one of the bathhouses. He (Vitya) entered and saw beautiful ladies dancing. And there was one man. He was playing the accordion..." (Emel'yanov 1921: 242).

In the recordings of the $19^{\text {th }}$ century, the image of a munchokuz'o is generally anthropomorphic. Some individual cases of witnessing a bathhouse man with zoomorphic features were recorded: "they put

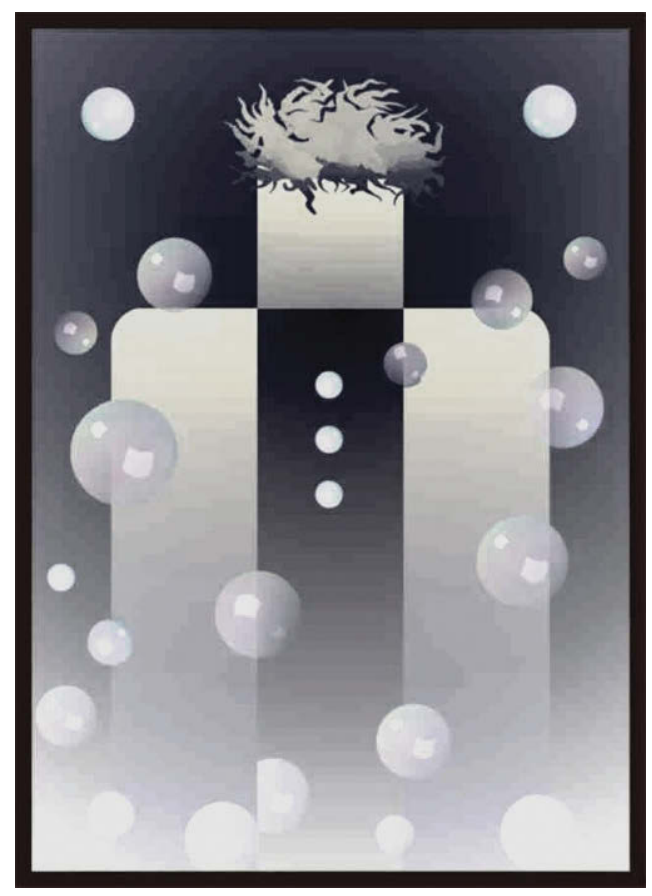

Illustration 2. Picture by Vladimir Nagovitsyn. Töd'y murt (The white man). 
straw around the bathhouse and burned it. When the bathhouse was on fire, mynchokukn'iks (bathhouse spirits) started flying to another bathhouse in the shape of roosters..." (Vereshchagin 2001: 142). At times, the bathhouse man appeared before people in several guises at the same time: "They (munchomurt girls) were dancing and dancing, and then their feet turned into calves' feet. Then the girls disappeared, and that man remained near him (Vitya). And we saw that he had hairy arms and hooves (...) Then he said, "kick me when you are leaving!" And he sat down right in the middle. And I stood up immediately and I kicked him hard on the back when I was leaving ... And when I turned around to look at the man one more time, I saw a stone in his place..." (Emel'yanov 1921: 243).

In modern mythological texts munchokuz'o also has a polymorphic image, but most often takes the shape of a human being:

Us'tem gine no muncho össe - polat'yn kuz', s’öd yyrs’iyo kyshnomurt. So yyrs'ize synasa, pe, puke, s’in”yosyz vozh dzhualo, pe.

I had barely managed to open the door of the bathhouse when I saw a woman with long black hair. She was combing it, and her eyes were green (FE 1982 ${ }^{21}$ );

S’öd yyrs’iyo, yyrs’iyez s’öd-s’öd.

With black hair; her hair was blacker-than-black (FE 1984²2);

Munchoye myni, pylas'kysa öy vuy - tuzh badzh'ym s'inmo, yyro piosmurt pyriz.

I went to the bathhouse but barely had I managed to wash myself when a man with big eyes and a big head entered (FE 199123). 
In modern recordings, munchomurt can also emerge as a kind of amorphous mythological creature white in colour: "Uyin vina pöz'tis'ko val no, korka pyray. Tare korkas' potko no - myncho az'yn töd'y ad'ami syle" ('I was making moonshine at night and I went into the house. When I came out, I saw a white man standing in the dressing room') (FE 20044), or having unclear zoomorphic features: "Mugoraz, pe, s'öd-s'öd gon budemyn" ('there was blackerthan-black fur on his body') (DE 199025).

Most often the bathhouse man is invisible, although he reveals himself with the help of different noises (rustling, knocking, stamping, with his voice or playing a musical instrument):

Pel' s'öraz kylis'kem argan kuara. Kylzis'kem no, valam: so kuara munchoys' kylis'ke vylem. Ösez us'tem no, nokine adzh'ymte, argan kuara no chusomem.

He heard someone playing the accordion. He listened to the music for a while, then realised that it was coming from the bathhouse. He opened the door but didn't see anyone, and the music stopped (FE 1982 26 ).

In many contemporary bailichkas the bathhouse spirit is envisaged on a sauna bench where he is taking some steam and whisking himself:

Polat'yn kuz's'öd yyrs’iyo kyshnomurt.

There was a woman with long black hair on the sauna bench (FE $1982^{27}$ ).

The sauna bench is the favourite place of the master of the bathhouse, which is why he doesn't like it when it is occupied:

Pydyz kynmem no shunskyny pyrem, polat'vylaz umme us'em, sapegze kyl'sa. Shop! karsa, badzh'ym pydchin'yze kurtchem. 
His feet were cold, so he went to the bathhouse to warm up. He took off by boots and fell asleep on the sauna bench. Chop! Someone bit him on his big toe (FE 200128).

The master of the bathhouse always lives and shows himself in an enclosed space, limited with walls. However, from time to time, he can also appear outside.

In Udmurt mythological stories one of the most popular motifs is the kidnapping or replacing of a child by the bathhouse spirit. According to beliefs, munchomurt kidnaps or replaces a child in the bathhouse while his or her parents are washing and the child is waiting for them in the dressing room. A number of precautionary measures should be taken in order to avoid this. For example, put scissors or some other metal object underneath the blanket the child is lying on. It was believed that if the child is christened, the bathhouse man will not be able to touch it. A child who had been 'replaced' by the bathhouse man was physically underdeveloped, crying all the time, not growing, not standing on his or her feet or trying to walk, but at the same time extremely gluttonous:

Pinalzy yalan zubkayn kyl'l'e. Tare so ug n’i bördy. Tshukaz'e 18 ares tyrmoz n'i, nosh so ug no veras'ky, ug no vetly.

The child is still in the cradle. He doesn't cry anymore. He turns 18 tomorrow, but he still neither walks nor talks (Kel'makov 1981: 139-140).

The bathhouse spirit can also steal a child (most often a girl) and raise her until she comes of age and, finally, gets married. Her miraculous saviour is usually a young man whom the girl lures in when he comes to the bathhouse at night or just passes by. The girl offers herself to him as a wife, albeit with a threat: 
18 ar ulysa, kyk yegit pios so munchoys'iz vayyny echeshil'l'am; polat' ulys' soles' kize kutil'l'am, nosh as'seos ug adsko, kyshno bas'tidy ke, lez'om, pe, shuo. Kyshkamenyzy piyash”yos soglash luil'l'am.

Two 18-year-old boys made a bet that at night they would take stones from the bathhouse; then someone grabbed at the arm of one of them from under the sauna bench, but they couldn't see anyone. They heard a voice that said that if that boy would take her as his wife, she would let him go. The boys were so scared that they agreed (FE $1984^{29}$ ).

If the boy agrees to take the changeling as a wife, the girl goes back to her house, where the deception is exposed: the parents see their real daughter, who regains her human shape:

Tan’i berto in’i nylen piyen nyllen korkayaz. Nyl pyrem no zubkays' nylez bas'tem. Pol vyle kushtem no-pil'is'kem, pushkys'tyz s'is'mem köshna paz'gis'kem.

Then the girl and the boy went to the girl's house. She entered the house and took the girl from the cradle in her arms. Then she threw her on the floor, and rot and dust poured out (Kel'makov 1981: 139-140).

According to mythological perceptions, when the bathhouse spirit kidnapped or replaced a child, he left a charred log or chock of wood in the child's place:

Shaytan ${ }^{30}$ lyktem no nylzes voshtem, so intyye muket pinal ponem: vylyz pinally tupa, nosh pushkyz pu köshnays'.

Shaytan came and replaced their girl with another child. She looked like a real child, but inside it was all rot and dust... (Ibid.). 
Quite often this kind of fate is cast on children by their own parents, who unwittingly shout "Shaytan bas'ton!' ('may you be taken by shaytan!') when they get angry with their children. These words, said in a rage, can sometimes be fatal. "The daughter wanted to put her shoes on, but she couldn't find her bast shoes. She had them in the bathhouse. She told her mother about this, who called her shaytan. The daughter stepped out of the house in silence and went to the bathhouse. In the bathhouse, shaytans adopted her, and in her place they sent back a girl from their own family... with bast shoes on..." (Vereshchagin 2001: 132).

According to beliefs and mythological stories, munchomurt is multifunctional. He punishes those who break certain taboos, for example if someone goes to the sauna at midnight, 'intruding' on the space of the bathhouse spirit. He can tickle or choke a person to death. In the past, the Udmurt protected themselves from the bathhouse spirit's tricks with "a piece of iron or metal used as an amulet" (Emel'yanov 1921: 120), and after the adoption of Christianity they did this with the help of a cross worn next to the skin, and Christian prayers mentioning God.

Overall, the following can be said about munchokuz'o: he lives in the bathhouse; does not have a fixed appearance; only reveals himself at night when people violate rules relating to time; and can manifest with the help of noises. He is perceived as an expressly evil creature with regard to humans ${ }^{31}$. People believed that he was only afraid of a four-eyed $\operatorname{dog}^{32}$ :

Pörtmas'kon nunal"yosy pörtmas'kyny potimy. Ogaz'yn sylo vylem kuin' muncho. Tolez' yugyt pishte. S'öramy n'yl' s'inmo puny kutimy val... Vot sytshe n'yl' s'inmo puny, pe, munchokuz'oyez syskyny bygate. So munchoosys', shapka kad' kuren', pitrasa munchokuz'o potiz. Punymy uyiz no öz bygaty kutyny, munchokuz'o doskaos ule vuiz pyryny. 
At Christmas we decided to go to a fancy dress party. There were three bathhouses in a line. The moon was shining so bright. We took a dog with four eyes with us... Because such a dog can gnaw and bite munchokuz'o. Munchokuz'o rolled out of those bathhouses like a brown hat. Our dog started chasing him, but couldn't catch him, that munchokuz'o slipped under the planking (FE $1985^{33}$ ).

People tried to hold the bathhouse spirit in esteem. When they entered the bathhouse, they asked for permission to wash themselves and thanked the spirit before leaving. They left a scoop or a basin with warm water as well as a whisk so that munchomurt could wash and whisk himself. In modern mythological texts, munchomurt is not perceived as an expressly evil spirit, but the Udmurt believe that if you see a bathhouse spirit, such as a korkamurt, it means bad luck, perhaps the death of someone close to you, a serious illness or some other trouble or disaster.

Another 'master' spirit of farmhouse buildings in Udmurt mythology is gidmurt/ gidkuz'o, gidut'is' or s'us'etka (the man/ master of the cowshed, the guardian of the cowshed). Unlike the mythological characters described above, the amount of information about gidmurt is quite limited in both $19^{\text {th }}$ century sources and modern recordings.

Analysis of folklore and ethnographic material enables us to say that gidkuz'o virtually never reveals himself to people, although it is possible to prove that he exists by the way he treats animals because in the cowshed where he lives the animals are well cared for and nourished. People even used to say that there is such a creature as nullis'kis', literally: someone who carries, which brings feed for cattle from other cowsheds. Most of all, gidkuz'o liked or disliked horses. It was believed that if gidkuz'o liked the horses of the master, he could steal hay and oats for them from neighbours. He would comb the manes and tails of his favourite horses and braid them. If he didn't like a horse, he would torture 
it at night riding it the whole night without rest and exhausting it with heavy loads (Pervukhin 1888: 92; Emel'yanov 1921: 119). In such cases people believed that the horse was 'unsuitable'/ug tupa, and it was recommended that they buy another horse, preferably a piebald one.

People also thought that the master of the cowshed could be seen after they performed certain actions. According to Nikolai Pervukhin, gidmurt could appear in front of people both as a human, "a little old man not taller than half an arshin... was riding a black horse" (Pervukhin 1888: 93); and in zoomorphic shape, "there was a bear on his hind legs standing right behind the water tub on the water carrying sledge" (Pervukhin 1888: 94). Sometimes gidmurt would leave "bear paw tracks behind him" (Emel'yanov 1921: 119).

In individual modern mythological texts gidmurt appears as an amorphous white creature:

Ogpol skal kyskis' kyshnomurt dory töd'y murt vuem. Skal kyskyny maza, pe, ug s'ot. Kalyk"yos, as gurtoossy, lyktil'l'am. Od'ekolon piyalayen yake kachyyen, pe, lez'yalo-ug koshky. Tyl dzhuatis'kod ke - yshe, peymytyn nosh, pe, pote. S'ör gurtys'pel'l'as'kis'ez vail'l'am. Achiz main ke s'urem lez'yany kutskem pörtmas'kysez, pel'l'am-maram no-so töd'y ad'ami byrem, potamys' no dugde.

Once a white man appeared in front of a woman milking a cow. He wouldn't let her milk the cow properly. The villagers came to help her. They were throwing perfume bottles (with perfume) and scissors at him, but he just wouldn't leave. When the lights were turned on he disappeared, but in the darkness he would appear again. They brought a healer woman from the neighbouring village. She also threw things at him and whispered something, and then the man disappeared and never came back again (FE 1985 $5^{34}$ ). 
In the old days, sacrifices were made to the master of the cowshed, just as to house spirit, in spring and in autumn. In spring, before putting cattle out to pasture, they made a sacrificial vow with bread and porridge, and the offering itself was made in autumn, when the young animals were mature enough. If a cow was sick, a wood grouse was sacrificed; if a horse was sick, a couple of pikes were offered to the spirit. Sometimes pikes were sacrificed because people believed that if they did so, the skin of their horses would be as shiny as a pike's scales. In this case, the pike was not boiled, but buried whole in the ground in the cowshed. Only family members took part in the offering ritual, and the procedure was similar to the one of making a sacrifice to korkakuz'o in the cellar (gulbech taka vös'an). Addressing gidkuz'o in his prayers, the master of the house asked him to fill his stockyard with strong healthy horses and dairy cows (Emel'yanov 1021: 119).

Expedition records from the second half of the $20^{\text {th }}$ century also contain information about offerings to the master of the cowshed:

Gidkuz'oly ke viro s'oto, dzh'az'egez gidyn vando. Achid gine s'em'yayenyd s'iis'kod. Kyl'e ke no, nokinly no ug s'oto. Ortche oz'y ik, kyz'y korkakuz'oly s'oto. Gidut'is'ly vaz'is'ko, “tynyd viro s'otis'ko" shusa.

If offerings are made to the spirit of a cowshed, a goose is killed there. Only family members can eat the goose. If any meat is left over, it is not given to anyone outside the family. The ritual is held in the same way as the ritual for the spirit of the house. Family members address the spirit of the cowshed saying "Here is a sacrifice for you" (FE 1989 ${ }^{35}$ );

“...Pudo-zhivotez ut', yu-n'an'med luoz, mushez ut', s'em'yame ut', nylpime ut'." Soye veras'ko no kiros ponis'ko. 
“...Protect my cattle, give me good bread crops, keep my bees, protect my family, protect my children." This is what I say and cross myself (FE 2012 $2^{36}$.

Analysis of the material we have enables us to draw a number of conclusions. Such spirits of domesticated space as korkakuz'o and the master of the cowshed/gidmurt are well-meaning creatures. Compared to the bathhouse spirit, they are described in a negative way to a lesser degree. A comment made by a researcher of the traditions of the northern Udmurt based on material he had collected in the $19^{\text {th }}$ century about the fact that the most ancient concept of house spirits is a bear, i.e. "...a figurative demigod of farmhouse buildings", is correct (Pervukhin 1889: 94). The totemic ancestor, whose benevolence in the past was essential to ensure the life and well-being of the entire family line, takes the shape of a spirit/master of the house. Later, when the period of the overriding of totemistic worldviews started, the totemic bear was replaced by a small old man with a beard, or just an old man, as "an ancestor/ progenitor, the head of a clan, consisting of numerous generations of kinsmen, dead or alive" (Krinichnaya 2004: 9).

In records made in recent years the images of mythological creatures under consideration as well as their functions transformed, with each of them more and more starting to look like an ordinary man, perhaps taking after a relative, neighbour or acquaintance, either dead or away from the home. The images mainly appear in dreams, bailichkas and narrations. Their main functions are predicting future events (death, disease and misfortune) or punishing people for violations of rules (human behaviour in nature and the community).

Different guises of mythological domestic spirits as well as of farmhouse buildings (the masters of the house, of the bathhouse and the master of the cowshed) evolved from zoo- and phyto- to anthropomorphic shapes. The last stage of evolution of these images is marked by the phantom of töd'y murt / 'the white man' and 
an amorphous visual shadow figure. Even with all the common features of these vague portrait specifications, their appearance can be differentiated depending on the location where the human being encounters the spirit master. A peculiar feature of modern mythological images is their predominantly acoustic nature: they reveal themselves by means of a number of audible signals (laughing, cackling, screaming, rustling or weeping, impact sounds, the sound of someone playing a musical instrument, dancing, etc.) and are also capable of reproducing human speech. To this extent, it can be said that their mythos returns to its archaic nature, i.e. syncretic and indivisible.

In the modern tradition, all of these images virtually lose their ambivalence with regard to people. They are regarded only as hostile creatures and lose their conspicuity in the hierarchical system.

\section{Abbreviations}

$\mathrm{NB}$ - notebook

$\mathrm{P} / \mathrm{Pp}$ - page/pages

FE - Folklore Expedition of the Institute of Udmurt Philology, Finno-Ugric Studies and Journalism at the Udmurt State University (Izhevsk, Russia)

FE UIHLL and USU - Folklore Expedition of the Udmurt Institute of History, Language and Literature, Udmurt Federal Research Centre at the Ural Branch of the Russian Academy of Sciences, and Udmurt State University (Izhevsk, Russia)

FDE - Folklore and Dialect Expedition of the Institute of Udmurt Philology, Finno-Ugric Studies and Journalism at the Udmurt State University (Izhevsk, Russia)

DE - Dialect Expedition of the Institute of Udmurt Philology, Finno-Ugric Studies and Journalism at the Udmurt State University (Izhevsk, Russia) 


\section{Notes}

1 In the past, the Udmurt built bathhouses on river banks or close to other bodies of water, or in their yards. In the national consciousness, the bathhouse was perceived as a dangerous place because it used to stand on the border of one's own and somebody else's space. Gradually people started building bathhouses in their yards, which is why we regard the mythological perceptions related to it within the context of domesticated space.

2 Researchers who study Udmurt families say that, for a number of reasons, the Udmurt had large extended families for a very long time (see Grishkina 1989: 210; Vladykin 1994: 202), which united three or four generations and consisted of $30-40$, sometimes even 60 people (Orlov 1999: 37).

${ }^{3}$ Udm. Gondyr "bear".

${ }^{4}$ It used to be very quiet in Udmurt houses, perhaps also to please korkakuz'o. This is how G. Vereshchagin described the traditional way of life: "If you want to learn about family life, enter the dwelling of a Votyak in winter and take a closer look at life among his family members ... It is all peace and quiet in the room; you will only hear a spindle spinning, the crackle of a burning log, the bast rustling, which resembles the rustle of the grass in the wind; occasionally you will also hear short, insignificant words about everyday things; if there are children in the house, you might also hear one of them crying because he was offended by another, but this weeping will not last long: as soon as the mother or father says something gentle, like "En bördy, gydyke!' '(Stop crying, darling!'), the child stops weeping and it is silent in the room once again. You will not hear any kind of row or quarrel" (Vereshchagin 1995: 21-22).

5 An old Russian length unit equal to about 71 centimeters or 28 inches.

6 Alnashi District, Udmurtia. NB. 4. P. 27.

7 Krasnogorskoye District, Udmurtia. NB. 5. P. 13.

8 Yakshur-Bod'ya District, Udmurtia. NB. 4. P. 45.

9 Yakshur-Bod'ya District, Udmurtia. NB. 2. P. 33.

${ }^{10}$ Grakhovo District, Udmurtia. NB. 3. P. 47.

${ }^{11}$ Sharkan District, Udmurtia. NB. 2. P. 20.

${ }^{12}$ Vavozh District, Udmurtia. NB. 4. Pp. 46-47.

${ }^{13}$ Sharkan District, Udmurtia. NB. 1. P. 6. 
${ }^{14}$ Alnashi District, Udmurtia. NB. 4. P. 5.

${ }^{15}$ Mozhga District, Udmurtia. NB. 6. Pp. 20-22.

${ }^{16}$ Grakhovo District, Udmurtia. NB. 3. P. 38.

${ }^{17}$ Yakshur-Bod'ya District, Kekoran village. Volume No. 4. P. 45.

${ }^{18}$ Alnashi District, Udmurtia. NB. 4. P. 20.

${ }^{19}$ Yakshur-Bod'ya District, Udmurtia. NB. 5. P. 5.

${ }^{20}$ An old Russian length unit equal to about 2 meters.

${ }^{21}$ Yakshur-Bod'ya District, Udmurtia. NB. 4. Pp. 47-48.

${ }^{22}$ Sharkan District of Udmurtia. NB. 1. P. 11.

${ }^{23}$ Sharkan District, Udmurtia. NB. 4. P. 2.

${ }^{24}$ Kez District, Udmurtia. NB. 2. P. 7.

${ }^{25}$ Sharkan District, Udmurtia. NB. 2. P. 40.

${ }^{26}$ Yakshur-Bod'ya District, Udmurtia. NB. 4. P. 38.

${ }^{27}$ Yakshur-Bod'ya District, Udmurtia. NB. 4. Pp. 47-48.

${ }^{28}$ Selty District, Udmurtia. NB. 5. P. 23.

${ }^{29}$ Sharkan District, Udmurtia. NB. 5. Pp. 10-13.

${ }^{30}$ Under the influence of Christian tradition, differentiated 'master' spirits become unified in a generalised image of an evil spirit (shaytan)/devil).

${ }^{31}$ Perhaps the main reason munchokuz'o was attributed with expressly negative features was because bathhouses used to stand furthest from all other buildings in the yard.

${ }^{32} \mathrm{~A}$ four-eyed dog is a dog whose fur around the eyes is much lighter or darker than its main colour. According to beliefs, such dogs can see evil spirits.

${ }^{33}$ Malaya Purga District, Udmurtia. NB. 2. P. 50.

${ }^{34}$ Malaya Purga District, Udmurtia. NB. 2. P. 50.

${ }^{35}$ Vavozh District, Udmurtia. NB. 4. P. 31.

${ }^{36}$ Kizner District, Udmurtia. NB. 3. P. 35. 


\section{References}

Belitser, V., Markelov, M., Sidorov, G. 1931. Udmurty [The Udmurt]. Izhevsk: Udmurtkniga.

Emel'yanov, A. 1921. Kurs po etnografii votyakov [A Course on Ethnography of the Votyaks]. Issue 3: Ostatki starinnykh verovaniy i obryadov $\mathrm{u}$ votyakov [Traces of Ancient Beliefs and Rites among the Votyak]. Kazan: Kazanskiy votskiy izdatel'skiy podotdel.

Glukhova, G. 1990. Obraz bannika v udmurtskoy neskazochnoy proze [The Image of the Spirit Living in Sauna in Udmurt Non-Fairytale Prose]. 6-aya ross. Univ. Akadem. Nauchno-prakticheskaya konferentsiya $\left[6^{\text {th }}\right.$ Russian Univ. Academ. Theoretical and Practical Conference. Part I]. Izhevsk: Udmurtskiy universitet, pp. 51-53.

Grishkina, M. 1989. Tipologiya udmurtskoy krest'yanskoy sem'i kon. XVII - per. pol. XIX vv. [Typology of the Udmurt Peasant Family at the End of XVII c. - First Half of XIX c.]. Materialy VI Mezhdunarodnogo kongressa finno-ugrovedov [Works of VI International Congress of Finno-Ugric Scholars]. Vol. 1. Moscow: Nauka, pp. 104-125.

Holmberg, U. 1927. Finno-Ugric, Siberian. The Mythology of All Races IV. Boston: Archaeological Institute of America.

Kel'makov, V. 1981. Obraztsy udmurtskoy rechi: Severnoye narechiye $i$ sredinnyye govory [Samples of Udmurt Dialects: the Northern Dialect and the Central Subdialects]. Izhevsk: Udmurtia.

Kel'makov, V. 1990. Obraztsy udmurtskoy rechi 2: Sredinnyye govory [Samples of Udmurt Dialects 2: the Central Subdialects]. Izhevsk: Udmurtia.

Krinichnaya, N. 2004. Russkaya mifologiya. Mir obrazov fol'klora [Russian Mythology. The World of Folklore Characters]. Moscow: Akademicheskiy proekt Gaudeamus.

Levkiyevskaya, E. 2006. Pragmatika mifologicheskogo teksta [Pragmatics of Mythological Texts]. Slavyanskiy i balkanskiy fol'klor. Semantika $i$ pragmatika teksta [Slavic and Balkan Folklore. Semantics and Pragmatics of the Text]. Issue 10. Moscow: Indrik, pp. 150-211.

Orlov, P. 1999. Veshchnyy mir udmurtov: K semantike material'noy kul'tury: Dissert. na soisk. uch. step. kand. nauk. [Udmurts' World of Things: On the Semantics of Material Culture. Cand. sci. diss.]. Izhevsk: Udmurtskiy universitet. 
Panina, T. 2017. Obrazy lesnykh dukhov v udmurtskoy mifologiy i fol'klore: III. Obyda (lesnaya zhenshchina) [Images of Forest Spirits in Udmurt Mythology and Folklore: III. Obyda (Forest Woman)]. Ezhegodnik finno-ugorskikh issledovaniy [Yearbook of Finno-Ugric Studies] 11 (2), pp. 53-67.

Pervukhin, N. 1888. Eskizy predaniy byta inorodtsev Glazovskogo uyezda [Essays about the Legends and the Everyday Life of Non-Russians of the Glazov District]. Eskiz 1: Drevnyaya religiya votyakov po ego sledam v sovremennykh predaniyakh [Essay 1: The Ancient Religion of the Votyak according to its Traces in Modern Legends]. Vyatka: Gubernskiy statisticheskiy komitet.

Pervukhin, N. 1889. Eskizy predaniy byta inorodtsev Glazovskogo uyezda [Essays about the Legends and the Everyday Life of Non-Russians of the Glazov District]. Eskiz 4: Sledy yazycheskoy drevnosti v obraztsakh ustnoy narodnoy poezii votyakov [Essay 4: Traces of Pagan Antiquites in Samples of Oral Folk Poetry of Votyak]. Vyatka: Gubernskiy statisticheskii komitet.

Pletneva, I. 1999. K semantike udmurtskogo vozho [On the Semantics of the Udmurt Vozho]. Problemy udmurtskoy i finno-ugorskoy filologii [Questions of Udmurt and Finno-Ugric Philology]. Izhevsk: Udmurtskiy universitet, pp. 245-250.

Shklyayev, G. 1989. Obryady i pover'ya udmurtov, svyazannyye s zhilishchem [The Udmurt's Rituals and Beliefs Related to the House]. Fol'klor i etnografiya udmurtov: obryady, obychai, pover'ya [Folklore and Ethnography of the Udmurt: Rituals, Customs, Beliefs]. Izhevsk: Udmurtskiy institut istorii, yazyka i literatury Uralskogo otdeleniya Rossiyskoy akademii nauk, pp. 28-43.

Shklyayev, G. [n.y.]. Korkamurt (domovoy) [Korkamurt (House Spirit)]. Mifologiya udmurtov: entsiklopedicheskiy slovar'. Rukopis' [Mythology of the Udmurt: Encyclopaedia] [Manuscript].

Slesareva, M. 2004. Zhanr bylichki v publikatsiyakh G. Vereshchagina [The Genre of 'Bylichka' (a short story/fable) in the Publications of G. Vereshchagin] G. E. Vereshchagin i etnokul'turnoye razvitiye narodov Uralo-Povolzh'ya: Sb. st. [G. Vereshchagin and the Ethnocultural Development of Peoples of Ural and Volga Regions. Collected Articles]. Izhevsk: Udmurtskiy institut istorii, yazyka i literatury Uralskogo otdeleniya Rossiyskoy akademii nauk, pp. 115-117. 
Slesareva, M. 2005. Mifologicheskiye obrazy: izmeneniye traditsii vo vremeni [Mythological Characters: Changing Tradition in Time]. Material'naya $i$ dukhovnaya kul'tura narodov Urala i Povolzh'ya: istoriya i sovremennost'. Materialy Mezhregional'noy nauchno-prakticheskoy konferentsii. [Material and Spiritual Culture of the Peoples of Ural and Volga Regions. Works from International Theoretical and Practical Conference]. Glazov: Glazovskiy gosudarstvennyy pedagogicheskiy institut.

Tronina, I. 2007. Zhanry i obrazy udmurtskoy mifologicheskoy prozy: Vypusk. kvalif. rabota / Ruk. T. G. Vladykina [Genres and Metaphores in Udmurt Mythological Prose. Graduation Thesis, Sci. Supervisor T. G. Vladykina]. Izhevsk: Udmurtskiy universitet.

Vereshchagin, G. 1995. Sobraniye sochineniy: V 6 t. [Collected Works: In 6 Vols.]. Vol. 1: Votyaki Sosnovskogo kraya [The Votyak of Sosnovka Region]. Izhevsk: Udmurtskiy institut istorii, yazyka i literatury Uralskogo otdeleniya Rossiyskoy akademii nauk.

Vereshchagin, G. 1996. Sobraniye sochineniy: V $6 t$. [Collected Works: In 6 Vols.]. Vol. 2: Votyaki Sarapul'skogo uyezda Vyatskoy gubernii [The Votyak of Sarapul District of the Vyatka Governorate]. Izhevsk: Udmurtskiy institut istorii, yazyka i literatury Uralskogo otdeleniya Rossiyskoy akademii nauk.

Vereshchagin, G. 2001. Sobraniye sochineniy: V 6 t. [Collected Works: In 6 Vols.]. Vol. 4: Fol'klor. Book 1: Udmurtskiy fol'klor: Predaniya. Legendy. Pobyval'shchiny. Skazki. Basni. Poslovitsy. Pogovorki. Zagadki [Folklore. Book 1: Udmurt Folklore: Traditions. Legends. Stories. Fairy Tales. Fables. Proverbs. Riddles]. Izhevsk: Udmurtskiy institut istorii, yazyka i literatury Uralskogo otdeleniya Rossiyskoy akademii nauk.

Vladykin, V. 1994. Religiozno-mifologicheskaya kartina mira udmurtov [The Udmurt's Religious and Mythological Worldview]. Izhevsk: Udmurtia.

Vladykina, T. 2009. Obrazy lesnykh dukhov v udmurtskoy mifologiy i fol'klore: I. N'ulesmurt (lesnoi chelovek/leshii) [Forest Beings in Udmurt Mythology and Folklore: 1. N'ulesmurt (Wood Spirit)]. Traditsionnaya kul'tura $v$ izmenyayushchemsya mire: Materialy VIII Mezhdunar. shkoly molodogo fol'klorista "Traditsionnaya kul'tura $v$ izmenyayushchemsya mire" $i$ seminara "Permistika: yazyk $i$ stil" fol'klora" [Traditional Culture in the Changing World: Proc. $8^{\text {th }}$ Int. School of Young Folklorist "Traditional Culture in the Changing world" and Seminar "Permistika: the Language and Style of Folklore"]. Izhevsk: Udmurtskiy institut istorii, yazyka i literatury Uralskogo otdeleniya Rossiyskoy akademii nauk, pp. 24-30. 
Vladykina, T., Glukhova, G. 2011. Ar-god-bergan: Obryady i prazdniki udmurtskogo kalendar'ya [Year Circle: Rituals and Celebrations of the Udmurt Calendar]. Izhevsk: Udmurtskiy universitet.

Vladykina, T., Panina, T. 2015. Obrazy lesnykh dukhov v udmurtskoy mifologiy i fol'klore: II. Palesmurt (polovinchatyy chelovek) [Forest Beings in the Udmurt Mythology and Folklore: 2. Palesmurt (HalfHuman Creature)]. Ezhegodnik finno-ugorskikh issledovaniy [Yearbook of Finno-Ugric Studies] 4, pp. 59-67.

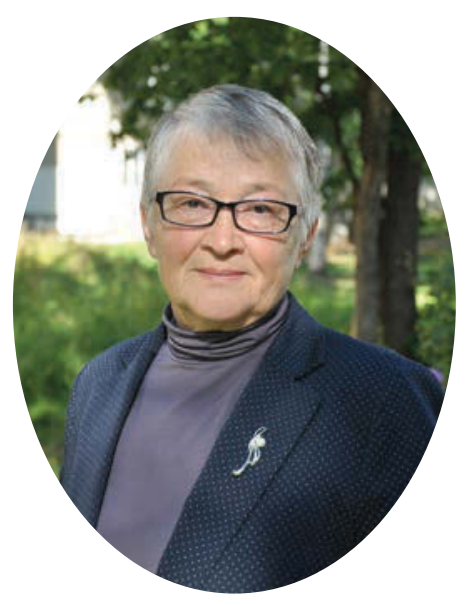

Tatiana Vladykina is ( $\mathrm{PhD}$ hab) a professor and leading researcher at the Udmurt Institute for Research in History, Language and Literature (Udmurt Federal Research Centre of the Ural Branch of the Russian Academy of Sciences). She has covered the range of topics in Udmurt folkloristics, especially mythology, specialising both in genre and in the treatment of the most important topics across genres.

e-mail: tgvladykina@mail.ru

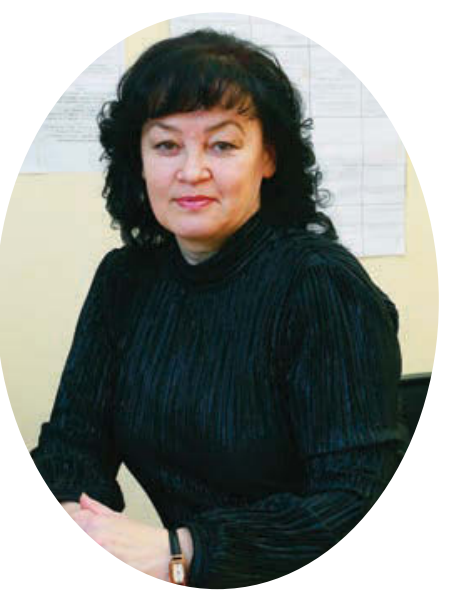

Galina Glukhova ( $\mathrm{PhD})$ is an associate professor and director of the Institute of Udmurt Philology, Finno-Ugric Studies and Journalism of Udmurt State University and teaches Udmurt literature and folklore. Her main field of interest is related to research on Udmurt and FinnoUgric folklore, Udmurt traditional culture, and the interaction of Udmurt folklore and literature. e-mail: galant@udm.ru 